\title{
Financial Digitalization and Regulatory Challenges for Japan
}

\author{
Kiyotaka Sasaki
}

\section{Introduction}

This chapter addresses the key features of financial digitalization, challenges, and regulatory responses from the perspective of a former regulator of the Financial Services Agency of Japan (JFSA). The key features of financial digitalization are summarized as the five Ds: Data, Decentralization, Diversification, Democratization, and Disruption. New regulations have been developed to address financial digitalization including oversight of new players, products and services. However, financial regulators around the globe have been facing disruptive challenges for effective and efficient supervision of financial digitalization in relation to domestic and crossborder cooperation, jurisdictions, and resources, especially human resources and IT. The anticipated further progress of digitalization in response to the New Normal with COVID-19 pandemic is posing additional challenges for financial regulators.

\section{The Five Ds}

Digitalization, recently also referred to as digital transformation (DX), has been advancing rapidly, affecting every aspect of our personal and social lives. The breakout of the COVID-19 pandemic since the beginning of 2020 and what has since been described as the transition to a "new normal" including remote work

\footnotetext{
K. Sasaki ( $\varangle)$

Hitotsubashi University, School of Business Administration, Tokyo, Japan

e-mail: kiyotaka.sasaki@hub.hit-u.ac.jp
} 
and social distancing to reduce the spread of the virus has been accelerating DX. Although there are a number of definitions of $\mathrm{DX},{ }^{1}$ the key features and implications of digitalization in the financial industry can be summarized by the five Ds: (i) Data, (ii) Decentralization, (iii) Diversification, (iv) Democratization, and (v) Disruption. The understanding of the five Ds is essential for the discussion of the responses by financial regulators undertaken in Sect. 3.

(i) Data The most distinctive feature of financial digitalization is that it centers around the use of data as opposed to the use of an IT infrastructure, such as hardware and software, which in the past drove IT development in the financial industry, also referred to as digitization.

The innovation in data management, most prominently exemplified by big data analysis, has dramatically increased the value of data as a source of new business opportunities. Collecting, analyzing and leveraging data for multiple purposes promises a competitive advantage for businesses. For example, leveraging data from financial transactions by combining it with data from ecommerce could allow financial service providers to better understand the consumption profiles of their customers and to offer services better fit to the individual needs of their customers (Financial Services Agency, 2019a, b, c). As a result, competition over the acquisition of data has intensified and respective touchpoints with customers have become more crucial for business success.

(ii) Decentralization The conventional financial system is characterized by a high degree of centralization, reflected by government regulation, central banks, and other centralized institutions including stock exchanges and clearing houses. However, digital distributed ledger technologies such as blockchain, which are used, for example, with crypto assets or virtual currencies, allow for decentralized systems without the central control functions exercised by, for instance, central banks (Financial Services Agency, 2020d). Instead, control functions are distributed among participants in the blockchain and there is no centralized oversight mechanism. This decentralization in financial transactions might be further promoted by decentralization in lifestyles and workstyles during the COVID-19 pandemic. Working remotely, which has been implemented to avoid infections while working at and commuting to centralized workplaces, also relies on digital tools to support the regional distribution of work teams.

(iii) Diversification Financial digitalization has been promoting the diversification of financial players as well as products and services. Increasingly, new players from non-financial industries, including Big Tech companies and platformers, have been entering the financial business space, in particular, payment

\footnotetext{
${ }^{1}$ Common definitions of these related terms are as follows: "Digitization transforms information on written paper or other media into data fit for analysis. Digitalization makes processes digital using digital innovation such as robotics process automation (RPA). Digital Transformation (DX) provides new services using analyzed data and transforms business models with additional values for clients" (Financial Services Agency, 2019b, p. 2).
} 
services. ${ }^{2}$ Conventional players such as banks have been expanding their collaboration with non-financial players under the so-called open banking strategy. Conventional banks have noted advantages of non-financial players including platformers in enhancing touchpoints with individual customers, and have increased their alliances with new players and their reliance upon them in developing customer relations (Basel Committee on Banking Supervision, 2019). This has led to increased diversification in terms of financial products and services such as crypto assets and mobile payments.

(iv) Democratization Diversification of financial service providers and enhanced competition among conventional and new players have been leading to a shift in business models from a business to customer ( $\mathrm{B}$ to $\mathrm{C}$ ) to a customer to business (C to B) model (Financial Stability Board, 2019). The conventional financial system has been dominated by banks and other traditional financial service providers on the supply side. However, with financial digitalization, improved and ubiquitous access to the internet, increased diversification, and intensified competition, private customers and other users of financial services have acquired more power. Thus, customer satisfaction (CX) and touchpoints with customers have become more critical for financial service providers.

(v) Disruption The first four of the five Ds mentioned above have had a disruptive impact on conventional financial firms, regulators, and supervisors. Financial digitalization, diversification of financial players and democratization of financial services in particular, are posing existential threats to the business models of existing conventional players (Financial Stability Board, 2019). Many financial firms have been struggling with a difficult business environment characterized by low interest rates and low profitability after the world financial crisis of 2008 (Financial Services Agency, 2017b). Financial digitalization poses yet another significant challenge.

Financial digitalization also represents a disruption for financial regulators and supervisors. Although financial digitalization can benefit customers and users of financial services, and ultimately can contribute to the positive development of the economy, a number of issues and challenges need to be addressed by regulators and supervisors including the depth and scope of their jurisdiction, an adequate regulatory framework, effective oversight, and enforcement (Basel Committee on Banking Supervision, 2018).

\section{Regulatory Responses and Challenges}

In my position as Director General for Strategy Development, I was responsible for the reform of the JFSA including its supervisory framework, organization, human resources, and IT from 2017 to 2019. Financial digitalization was an important part of

\footnotetext{
${ }^{2}$ Since 2017, non-financial service providers such as PayPay, Line Pay, and au-Pay have been allowed to provide payment services in Japan, subject to JFSA's supervision.
} 
the background and a driver of the reform. The regulatory responses to digitalization constitute a top priority in the ongoing reform process.

\subsection{Visions Guiding the Regulatory Response to Financial Digitalization}

The purpose and mission of the JFSA was revisited as part of the JFSA reform. It was reconfirmed that the JFSA purpose was to contribute to sustainable economic growth and the welfare of society. Based on this purpose, the vision of JFSA was redefined as follows (Financial Services Agency, 2018a):

- A better balance between effective financial intermediation, and the safety and soundness of the financial system

- A better balance between market function and market integrity

- A better balance between convenience for users and protection of users.

The actual balancing in each vision statement can vary depending on economic conditions and priorities stipulated by JFSA's policy, but ensuring a balance by keeping the ultimate purpose and mission of JFSA in mind is important.

Following the three parts of the vision, the policy on a regulatory response to financial digitalization was developed by focusing on the promotion of innovation beneficial to users and society at large. Financial digitalization must not only serve the interests of financial firms, but also of users and society. Furthermore, digitalization is a tool or means to increase customer satisfaction and welfare. It is not an ultimate goal in itself.

Based on this vision, JFSA has developed innovation-friendly initiatives including FinTech Innovation Hub, sandboxes for new services/products, and open laboratories with private firms (Financial Services Agency, 2019c).

\section{Regulation of New Services and Products}

Conventional financial regulations are established separately for each financial industry such as banking and insurance. Typically, licensing for entering into business and ongoing supervisory oversight to ensure the safety and soundness of each firm are required. However, when new players from non-financial services are interested in specific services or products, for example payment, to reap the economic benefit from combining respective users' data with non-financial services such as ecommerce, financial services provided by conventional players become un-bundled by these new players, who provide specific mono-line services rather than full-line services. In this case, service- and product-based regulation needs to be applied to new players to ensure a level playing field for the same services among conventional and new players (Financial Stability Board, 2019).

For certain products and services, the existing regulatory framework can no longer be applied and a new regulatory framework will have to be introduced. For example, 
new regulation for virtual currencies as a means of payment was introduced in 2017 in Japan and a supervisory oversight for trading platforms was implemented (Financial Services Agency, 2018b). A regulatory requirement for smaller amounts of remittance was reduced for money remittance services, which are attracting new tech players. New regulations for cross-product portal services have also allowed new non-financial players to market various products across the financial industry to benefit customers. ${ }^{3}$

In addition to "hard" law and regulations by the government and regulatory agencies, soft law or self-regulation by private firms often appears to be more efficient and effective in addressing financial digitalization. ${ }^{4}$ Due to the speed of innovation and increasing complexity of the technology underlying new products, closer collaboration between regulators and self-regulatory bodies is necessary to properly regulate financial digitalization.

\section{Supervisory Oversight}

Besides the regulatory responses to financial digitalization, issues related to supervisory oversight of firms and products also require special consideration.

First, "digital governance" becomes an important element in the oversight of financial digitalization. In the conventional supervisory oversight of financial firms, the effectiveness of IT risk management including IT system development and consolidation used to be major issues in carrying out reviews. Even before DX developed as far as it has today, since IT infrastructure has become critical for the success of financial business, financial firms have been required to develop an IT strategy that enables them to provide sophisticated products and services in line with their business strategy. Thus, IT governance at financial firms that align IT strategy with business strategy and ensure effective internal control of operational processes have become critical for financial supervision (Financial Services Agency, 2020b). Under the conditions of ongoing digitalization or DX that go beyond conventional IT innovation, IT governance needs to be replaced or transformed as digital governance to ensure the alignment of DX with the business model or mission that financial firms pursue.

The digitalization strategies that financial firms develop should be aligned with their business model as well as their purpose and mission, that is, the creation of shared value (CSV) for their users and society. Digitalization is a means to achieve CSV and not an ultimate goal in itself. It needs to be well designed to reflect the purpose and mission of the firm. Digitalization, which will continue to contribute to CSV, needs to be supported by a sustainable innovation cycle, which allows firms to exploit new business opportunities within a sustainable business model (Financial Services Agency, 2020c).

\footnotetext{
${ }^{3}$ For both amendments, see Financial Services Agency (2020a).

${ }^{4}$ The rules and guidelines developed by JVCEA (Japan Virtual and Crypto Assets Exchange Association) as a self-regulatory organization are good examples. See https://jvcea.or.jp/.
} 
Second, oversight with the conventional "three lines of defense" model needs to be adjusted as financial digitalization progresses. ${ }^{5}$ An effective digital governance must ensure that business models for new digitalized products and services are well designed and that the risk appetite of firms is sufficiently contained. The supervisory review of the three lines of defense, i.e., business (first line), risk management (second line), and internal audit (third line), constitutes an essential prerequisite when it comes to ensuring the effective functioning of digital governance. In particular, risk management for operational risks including IT and cybersecurity as well as compliance and conduct risks such as customer protection and AML/CFT, will require enhanced oversight. ${ }^{6}$ A deep-dive analysis to identify deficiencies in business models, governance, or corporate culture is also useful in the evaluation of possible root causes.

Third, cooperation with other agencies, both domestic and cross-border, is necessary. Since new players under financial digitalization are mostly from the nonfinancial sector, financial regulators need to collaborate with relevant non-financial agencies. In addition, as data and their value are crucial for financial digitalization, cooperation is also required not only with the competent agencies responsible for customers' privacy protection, but also with those responsible for anti-monopoly and national security in each jurisdiction. Cross-border cooperation is more critical for oversight under financial digitalization, since digitalized products and services easily cross national borders. For example, an oversight of crypto assets using blockchain technology poses serious challenges in this regard. Differences in the development of legal frameworks for digitalized financial services around the globe including the establishment of effective regulatory bodies remain obstacles for cooperation in information exchange and enforcement.

\section{Cyber Risk Management}

In response to the progress of DX, enhanced cyber risk management at private firms as well as supervisory oversight should be in place. Cyber-attacks have been noted as increasing risks for the financial industry even prior to DX due to its highly complex and sophisticated IT infrastructure and the potential systemic impact of cyberattacks on economies and societies. JFSA developed its first strategy on cyber security for the financial industry in 2015 (Financial Services Agency, 2015), and conducted supervisory oversight for cyber risk management through off-site and onsite monitoring. JFSA has also organized a series of industry-wide drills for cyber risk management among financial firms referred to as the Delta Wall (Financial Services Agency, 2020e).

In response to the rapid progress of DX and increasing reliance by financial firms on third-party service providers for DX, JFSA has noted higher risks of cyberattacks

\footnotetext{
${ }^{5}$ Since the global financial crisis of 2008, the concept of the three lines of defense model for effective internal control among financial firms has been developed and shared among financial regulators around the globe. Business promotion departments at financial firms should be the first line of defense, with risk management/compliance functions as the second, and internal audit as the third. These three should be effectively developed as control functions.

${ }^{6}$ See anti-money laundering (AML) and combating the financing of terrorism (CFT).
} 
and updated its strategy in 2018 including enhanced international cooperation for cyber security (Financial Services Agency, 2018c).

\section{Technology for Supervisory Oversight (SupTech)}

In addition to the above changes and adjustments required for supervisory oversight in the process of financial digitalization, IT infrastructures to support such oversight are also necessary. Private financial firms have been engaged in FinTech and DX to establish new businesses. They have also been developing IT for regulatory compliance including risk management and regulatory reporting (RegTech). With the advancement of FinTech and RegTech among private firms, financial regulators need to develop their own IT for supervisory oversight or SupTech (Broeders \& Prenio, 2018). However, it takes time for the development of SupTech, since it is normally designed after FinTech and RegTech among private firms. Gaps between the development of SupTech and FinTech/RegTech may become wider. As a result, SupTech risks being left far behind FinTech/RegTech. An idea to develop a kind of ecosystem to fill in the gaps, for example, by embedding the needs for SupTech into the development of FinTech/RegTech has been under discussion between JFSA and the private sector including financial firms and IT companies.

Similar challenges are relevant with regard to human resources for supervisory bodies (Financial Services Agency, 2017a). In addition to the existing experts on IT risk management, professionals with expertise in blockchain, cybersecurity, and DX are required.

\section{Customer Education}

In order to maximize the benefits of financial digitalization for users, customer education for financial transactions needs to be reviewed. In addition to conventional financial literacy, literacy of digitalized products and services are also advisable for customers. Such literacy should cover knowledge about cyberattacks and more sophisticated financial crime using digitalized tools.

\section{New Issues Under COVID-19}

In addition to financial digitalization's rapid development and the regulatory responses for the past couple of years, the outbreak of the COVID-19 pandemic in early 2020 has been posing new issues and challenges for financial firms as well as for regulators (Financial Stability Board, 2020).

\subsection{Acceleration of $\mathrm{DX}$}

Under the COVID-19 pandemic, we need to adapt to the New Normal, including social distancing and remote work using online tools. Due to a number of measures 
taken against the infection including the lockdown of cities, the global economy has been negatively affected and a number of companies have been forced to change their business models or even close their businesses. ${ }^{7}$ As an effective means to avoid the infection, DX has been accelerating in aspects of our lives that are not limited to financial services. I call this acceleration of DX under the COVID-19 pandemic "COVIDX." COVIDX is expected to continue advancing even after the pandemic.

\subsection{The Three Ss}

Financial firms need to review their business models to adapt to the changes brought about by the pandemic. Since COVID-19 represents a threat to human lives, issues such as health, hygiene, safety, employment, education, and the role of communities have taken on much more importance than they did before the pandemic. The aspect of sustainability, but also solidarity to overcome divisions within society, are being recognized as invaluable. In this respect, attention to the three Ss comprising society, sustainability, and solidarity provides a useful framework when reviewing business models during and after COVID-19.

\subsection{Role of the Financial Sector and Financial Digitalization}

Compared with the global financial crisis of 2008, the financial sector has been safe and sound under the COVID-19 pandemic since the pandemic is caused by a virus and not by reckless financial firms or traders. However, the role of the financial sector to support economies and to overcome the effectives of the pandemic including production of vaccines for COVID-19 is increasingly acknowledged. Financial digitalization can benefit users and society at large by providing new products and services that fit the New Normal under COVID-19 conditions. Also, digital money or other nonface-to-face means of payment have been better received by individuals who want to avoid infection by limiting the use of paper money or face-to-face transactions. In this regard, financial digitalization also benefits people's health and hygiene.

The JFSA has been stressing the more positive role of the financial sector during and beyond the current pandemic with a focus on the three Ss. It also keeps reminding the financial sector that financial digitalization is not a goal in itself, but a means to improve customer satisfaction and welfare, and of the precautions necessary to control the heightened risk of cyberattacks (Financial Services Agency, 2020c).

\footnotetext{
${ }^{7}$ In Japan, a number of measures have been taken by the government to support industries that have been severely affected by the pandemic and to encourage business model changes. See Cabinet Office (2020).
} 


\section{References}

Basel Committee on Banking Supervision (BCBS) of the Bank for International Settlements. (2018, February). Sound practices: Implications for fintech developments for banks and bank supervisors. https://www.bis.org/bcbs/publ/d431.pdf

Basel Committee on Banking Supervision (BCBS) of the Bank for International Settlements. (2019, November). Report on open banking and application programming interfaces. https://www.bis. org/bcbs/publ/d486.pdf

Broeders, D., \& Prenio, J. (2018, July). Innovative technology in financial supervision (suptech) - the experience of early users. Financial Stability Institute of the Bank for International Settlements. https://www.bis.org/fsi/publ/insights9.pdf

Cabinet Office. (2020, December 8). Comprehensive economic measures to secure people's lives and livelihoods toward relief and hope. https://www5.cao.go.jp/keizai1/keizaitaisaku/2020-2/202 01208_economic_measures.pdf

Financial Services Agency. (2015, July). Kin'yū bun'ya ni okeru saibāsekyuriti kyōka ni muketa torikumi hōshin ni tsuite [On Policies towards enhanced cyber security for financial industry]. https://www.fsa.go.jp/news/27/20150702-1/02.pdf

Financial Services Agency. (2017a, September). Henkakuki ni okeru kin'yū sābisu no kōjō ni mukete: Kin'yū gyōsei no koremade no jissen to kongo no hōshin [Towards improving financial services in a changing era: Past practices and future policies of financial administration]. https://www.fsa. go.jp/news/30/For_Providing_Better_Financial_Services.pdf

Financial Services Agency. (2017b, October). Heisei 28 jimu nendo kin'yū repōto [Progress and Assessment of the Strategic Directions and Priorities 2016-2017]. https://www.fsa.go.jp/news/ 29/Report2017.pdf

Financial Services Agency. (2018a, June). Kin'yū kensa • kantoku no kangaekata to susumekata [JFSA's supervisory approaches: Replacing checklists with engagement]. https://www.fsa.go.jp/ news/30/wp/supervisory_approaches_revised.pdf

Financial Services Agency. (2018b, August 10). Kasōtsūka kōkan gyōshatō no kensa • monitaringu chūkan torimatome [Interim summary of inspection and monitoring of virtual currency exchange service providers]. https://www.fsa.go.jp/news/30/virtual_currency/20180810-2.pdf

Financial Services Agency. (2018c, October). Kin'yū bun'ya ni okeru saibāsekyuriti kyōka ni muketa torikumi hōshin [Policies towards enhanced cyber security for financial industry]. https://www. fsa.go.jp/news/30/20181019/cyber-policy.pdf

Financial Services Agency. (2019a, January 16). Kin'yū kikan niyoru jōhō no rikatsuyō ni kakaru seido seibi nitsuite no hōkoku [Report on the regulatory framework for the use of data by financial institutions]. https://www.fsa.go.jp/singi/singi_kinyu/tosin/20190116/houkoku.pdf

Financial Services Agency. (2019b, June 20). Kin'yū monitaringu ni okeru dejitaraizēshon no torikumi jōkyō [Current status of digitalization in financial monitoring]. https://www.fsa.go.jp/ news/30/20190620_joubun/01.pdf

Financial Services Agency. (2019c, September). Tayō na fintekku sutēkuhorudā to no taiwa ka ra mieta 10 no shuyō na hakken [10 key findings from the conversation with various FinTech stakeholders]. https://www.fsa.go.jp/news/r1/sonota/FIH_Report.pdf

Financial Services Agency. (2020a, March) Kin'yū sābisu no riyōsha no riben no kōjō oyobi hogo wo hakaru tame no kin'yū shōhin no hanbaitō ni kansuru hōritsutō no ichibu wo kaiseisuru hōritsuan setsumei shiryō [Explanatory material related to the proposal for a partial amendment of laws regulating the sales of financial products to improve the convenience and protection of users of financial services]. https://www.fsa.go.jp/common/diet/201/01/setsumei.pdf

Financial Services Agency. (2020b, June). Kin'yū kikan no IT gabanansu tō ni kansuru chōsa kekka repōto [Report on IT governance at financial institutions]. https://www.fsa.go.jp/news/r1/ 20200630-2/it_02.pdf

Financial Services Agency. (2020c, August). Fight against COVID-19 and develop a better post-COVID society. https://www.fsa.go.jp/en/news/2020/20200831/201204_JFSA_priorities_ for_July2020_June2021.pdf 
Financial Services Agency. (2020d, October 20). Bunsangata kin'yū shisutemu ni okeru gabanansu [Governance for decentralized financial system]. https://www.fsa.go.jp/policy/bgin/20201020_ Fintech_Association_presentation_JP.pdf

Financial Services Agency. (2020e, October 13). [Kin'yū gyōkai ōdanteki na saibāsekyuriti ensh $\bar{u}$ (Delta Wall V)] ni tsuite [Financial industry-wide cybersecurity exercise (Delta Wall V)]. https:// www.fsa.go.jp/news/r2/20201013.html

Financial Stability Board. (2019, December 9). BigTech in finance: Market developments and potential financial stability implications. https://www.fsb.org/wp-content/uploads/P091219-1. pdf

Financial Stability Board. (2020, November 17). COVID-19 pandemic: Financial stability impact and policy responses. https://www.fsb.org/wp-content/uploads/P171120-3.pdf

Open Access This chapter is licensed under the terms of the Creative Commons AttributionNonCommercial-NoDerivatives 4.0 International License (http://creativecommons.org/licenses/bync-nd/4.0/), which permits any noncommercial use, sharing, distribution and reproduction in any medium or format, as long as you give appropriate credit to the original author(s) and the source, provide a link to the Creative Commons license and indicate if you modified the licensed material. You do not have permission under this license to share adapted material derived from this chapter or parts of it.

The images or other third party material in this chapter are included in the chapter's Creative Commons license, unless indicated otherwise in a credit line to the material. If material is not included in the chapter's Creative Commons license and your intended use is not permitted by statutory regulation or exceeds the permitted use, you will need to obtain permission directly from the copyright holder.

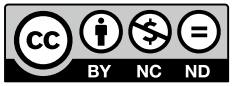

